\title{
Zoroastranisme en die ontstaan van apokaliptiese denke
}

\author{
Marius $\mathrm{Nel}^{1}$ \\ Departement Ou-Testamentiese Wetenskap \\ Universiteit van Pretoria
}

\begin{abstract}
Zoroastrianism and the origin of apocalyptic thinking

Where and how did apocalyptic thought originate? Ancient cultures looked at the world as a changeless essence. A battle between good and evil, order and chaos is distinctive of the world. But the victory of good and order is guaranteed. At the turn of the second millennium BCE the proto-Indo-Iranians trekked from what today are the Steppes of Russia, through Caucasia to different destinations. The Vedic Indians established themselves in the rich Indus valley, while the other group settled in the east of what is the Iran of today. The Vedic Indians preserved the ancient doctrine of a changeless universe, while an Iranian prophet by the name of Zarathustra, often better known by the Greek version thereof, Zoroaster, started teaching that this world would come to an end. Zoroaster subscribed to the doctrine of a battle between good and evil but, for the first time in history formulated the belief that a final victory of good over evil would lead to a new earth and a new heaven.
\end{abstract}

\section{INLEIDING}

Christene leef van die verwagting dat die wêreld soos dit tans bestaan, tot 'n einde sal kom. 'n Nuwe wêreld sal tot stand kom, waarin goed oor kwaad sal oorwin, en die menslike en bo-aardse agente van die bose vir ewig gestraf gaan word. Die uitverkorenes beërwe 'n nuwe, getransformeerde wêreld wat volmaak sal wees, tot in ewigheid. Waar kom dié verwagting vandaan? Is dit 'n eksklusief Joodse of Christelike beskouing? Vir baie eeue het die groot beskawings, die Egiptiese, Mesopotamiese en Vedies-Indiese wat die derde en tweede millenia

\footnotetext{
${ }^{1}$ Hierdie is 'n artikel wat voortvloei uit 'n postdoktorale genootskap wat dr M Nel in die Departement Ou-Testamentiese Wetenskap, Fakulteit Teologie, Universiteit van Pretoria, in samewerking met prof dr D J Human voltooi het. Dr Nel is ook 'n navorsingsassosiaat in die Departement Ou-Testamentiese Wetenskap.
} 
voor Christus geheers het, nie so 'n verwagting gehad nie. lewers het omstandighede tot 'n nuwe verwagting aanleiding gegee wat die wêreld se verbeelding aangegryp het en tot 'n nuwe toekomsverwagting gelei het. In dié artikel word gekyk na die ontstaan van apokaliptiese denke by die Iranese profeet Zoroaster, en gevra na die lewensomstandighede wat 'n breuk met die wêreldbeskouing en toekomsverwagting van die antieke mens moontlik gemaak het. Die wêreldbeeld van die proto-Indo-Iranese stamme wat in die tweede helfte van die derde millennium op die groot oop steppe van suidelike Rusland gebly het, was gebaseer op 'n goddelik daargestelde orde wat basies tydloos en onveranderlik was, alhoewel alles nie altyd kalm en rustig was nie (Yasna 44.3-5, 7).

Teen 2000 vC of vroeër het die groep in twee gedeel: die Indo-Ariane wat deur Sentraal-Asië en Afghanistan na die Indusvallei getrek het, en die Iranese (vir meer inligting oor die proto-groepe, vgl Basham 1967:34-68 en Wolpert 1982:2-173). Die Vediese Indiërs het steeds na die wêreld gekyk asof dit in 'n tydlose ekwilibrium vasgevang is. Die Iranese het met dié wêreldbeskouing, wat in breë trekke ook deur die Egiptenaars en Mesopotamiërs aangehang is, gebreek. Die Iranese profeet, Zarathustra, of soos hy meer bekend is by sy Griekse naam, Zoroaster, was hiervoor verantwoordelik. Hy beskou alle bestaan as die geleidelike realisering aan die hand van 'n goddelike plan wat uitloop op die uiteindelike vervulling van die plan en ' $n$ einde aan alles soos dit tans bestaan, sodat slegs die volmaakte tot in ewigheid voortbestaan ('n inleiding tot die geskiedenis en leerstellings van Zoroastranisme kom voor by Zaehner 1961 en Boyce 1975, 1981, 1991, 1992).

\section{BIOGRAFIE}

\section{$2.1 \quad$ Tyd}

Daar bestaan twee teorieë oor wanneer Zoroaster leef en optree. 'n Zoroastraanse tradisie meen dat die profeet 258 jaar voor Aleksander die Grote leef, in die middel van die sesde eeu (Kingsley 1990:245-264). Die tradisie berus egter op 'n Griekse fiksie (Cohn 2001:77). 'n Alternatiewe siening is dat hy veel vroeër geleef het, tussen 1500 en $1200 \mathrm{vC}$, toe die Iranese met vee geboer het (Boyce 1991:1-3). Die beelde ontleen uit werk wat aan die profeet toegeskryf word, verwys na die gebruike en denkpatrone van die tradisionele pastorale gemeenskap (Eduljee 1980:104). Dié gemeenskap het in die tweede helfte van die tweede millennium in Iran bestaan. Zoroaster het heel moontlik in dié tyd 
geleef. "Zarathustra" beteken "hy wat met kamele boer" of "hy wat aktiewe/werkende kamele het", wat inpas by dié wêreld (Yasna 44.18 - die Yasna is deel van die Avesta, die teks wat tydens die erediens - yasna $=$ aanbidding - gelees word, en bestaan uit 72 genommerde dele).

\subsection{Plek}

Dit is nie bekend waar Zoroaster gebore is nie. Sommige meen dat dit nie ver van die oorspronklike tuisland van die Iranese is nie, suid van die Oeralgebergte, in wat vandag die noorde van Kazakstan is. Ander meen dat dit eerder iewers op die migrasieroete na die suide is, in die ooste van Iran of weste van Afganistan. Wat wel bekend is, is dat die mense van Zoroaster uiteindelik in die ooste van Irak vestig.

\subsection{Werk}

Zoroaster begin sy loopbaan as priester van die ouer godsdiens van die Iranese. Hierin is Zoroaster uniek tussen die grondleggers van die wêreld se belangrikste godsdienste, wat nie in die amptelike kultus gedien het nie (Cohn 2001:78). Van die ouderdom van sewe jaar is die Iranese priester professioneel opgelei. Hy leef in die eeue-oue godsdiens, maar Zoroaster se denke is avontuurlik nuut. 'n Ou tradisie wil sien dat die profeet teen die ouderdom van twintig jaar vir enkele jare rond reis en besoek by verskeie sieners en profete aflê. lewers in dié tyd beleef Zoroaster hallusinasies (of verligtings, afhangende van die hoek waaruit gekyk word) waarin hy die groot god Ahura Mazda (ook Ahuramazda, "Heer Wysheid") sien en hoor. Die god is omring met ses skitterende figure. Die ervaring lei tot 'n roepingsbewustheid waarin hy homself as goddelik geordende profeet van 'n geloof sien wat grootliks van die tradisionele verskil (Yasna 44).

Zoroaster poog hoegenaamd nie om die geloof van sy vaders te versaak nie, maar eerder om dit te hervorm. Hy word nie in sy eie omgewing aanvaar nie, en trek dan weg. Die hof van prins Vishtaspa verwelkom hom en eer die profeet, terwyl alle pogings aangewend word om sy leerstellings wyd te verkondig. Zoroaster verkondig ' $n$ vreugdevolle onsterflikheid vir elke mens wat sy boodskap glo (Yasna 30). Onsterflikheid was in die antieke geloof gereserveer vir prinse, soldate en priesters (Cohn 2001:78). Gou maak Zoroaster genoeg vyande dat die prinsdom waar hy bly, deur omringende prinsdomme aangeval word. Zoroaster se troepe is egter sterker en die geloof oorleef (Boyce 1991:23). 
Gedurende die eerste duisend jaar van die voortbestaan van die geloof word dit gevestig oor groot areas van noordoostelike en oostelike Iran. Stadig dring dit ook westelike Iran binne, wat intussen in die hande van die Mede in die noorde en die Perse in die suide beland het (Boyce 1991:39). In die sewende eeu word die oorerflike priesterdom van westelike Iran, die magi, bekeer tot Zoroastranisme. Die Persiese monarg, Kores die Grote, wat die eerste Iranese ryk in 549 vC vestig, was heel moontlik 'n Zoroastriaan. Tydens die regering van die magtige Achaemeneïese regeerders, wat twee eeue duur, bly Zoroastranisme die amptelike ryksgodsdiens. Selfs tydens die Seleukidiese regering van die Masedoniese dinastie bly Zoroastranisme die keuse van die bevolking. En tydens die agthonderd jaar van die tweede of Partiese en derde of Sasaniese ryke funksioneer dit weer as ryksgodsdiens (Boyce 1991:41-59 en Cohn 20012:78-79).

In die middel van die sewende eeu nC onderwerp die Moslems vanuit Arabië die Sasaniese regering. Oor die eeue bly die tradisie voortleef onder Moslemregerings, ten spyte van godsdienstige vervolging. Teen 1970 is daar 130 000 Zoroastriane wêreldwyd, waarvan 90000 op die Indiese subkontinent, waarheen hulle voorouers gevlug het van Moslem-oorheersing. Hulle staan as Parsis bekend. In Iran is daar vandag slegs 20000 aanhangers van Zoroastranisme oor.

Die impak van Zoroastranisme is egter veel groter as waarop die getalle dui. Vir verskeie eeue voor Christus is die leerstellings van Zoroaster wyd versprei en bespreek. Die invloed daarvan op die Joodse en Christelike wêrelden tydsbeskouing was groot.

\subsection{Geskrifte}

Die heilige geskrifte van Zoroastranisme staan bekend as die Avesta, wat heel moontlik "Gesaghebbende Uitinge" beteken. Die bestaande Avesta is slegs 'n kwart van die oorspronklike, en hierdie gedeelte is eers tydens die vyfde of sesde eeu $\mathrm{nC}$ neergeskryf. Voorheen is die boek in priestelike skole mondeling oorgedra. Heel moontlik is die inhoud vir twee millenia getrou oorgedra, soos die geval met die Rig Veda ook was (vgl Nyberg 1983:415-419 vir meer inligting oor die samestelling van die Zoroastraanse kanon).

Die Avesta bevat sewentien liedere wat deur Zoroaster self gedig sou wees, die Gathas. Die res van die boek dateer uit 'n later periode en word ook 
die "jonger" Avesta genoem. Navorsers stem saam dat die leerstellings in hierdie deel egter ook van Zoroaster afkomstig is (Nyberg 1983:66).

Dan is daar ook die Pahlavi of Middel-Persiese boeke wat 'n finale resensie in die negende of tiende eeue nC beleef, en 'n opsomming bevat van die oorspronklike Avesta (die Dinkard) asook lang gedeeltes wat direk uit die oorspronklike Avesta vertaal is (Darmesteter 1883). Van belang vir 'n studie van die wêreldbeeld van Zoroastranisme is een van die Pahlavi, die Bundahishn ("Skepping"), wat handel oor die ontstaan en beëindiging van die geordende wêreld.

Die wêreldbeeld staan naby aan dié van die antieke Iranese gemeenskap, wat vir historiese redes ook noue ooreenkoms met die Vediese vertoon (Cohn 2001:81). Die begrip van 'n allesomvattende orde staan voorop. Die Indo-Iranese woord verander van rita na asha, maar die konsep bly ewe sentraal. En die pantheon wat die orde handhaaf bly ook in die verskillende teologiese stelsels dieselfde. Die god van vuur, Atar, het dieselfde natuur en funksies as Agni. Haoma is dieselfde god as Soma en die riviergodin Arasvati figureer in beide godedomme. Die Avesta bevat 'n aantal yashts, or lofliedere wat aan antieke, pre-Zoroastriaanse gode gewy word. Die enigste vertaling wat hiervan bestaan, is die gedateerde werk van Darmesteter (1883) wat gedateer is en in vele opsigte tekort skiet.

Die Avesta verskil egter van die Rig Veda in hoe dit na die rol van die belangrike gode kyk wat die wêreld tot stand gebring het en steeds vir die onderhoud daarvan verantwoordelik is. Indra word slegs skrams gemeld, en dan as demoon. Varuna is slegs as 'n obskure god teenwoordig. Hierteenoor staan die Iranese Mithra duideliker uit as in die Rig Veda. Die god wat egter die Avestaanse wêreldbeeld oorheers is Ahura Mazda. Of die Vediese priesters van hom geweet het, is nie duidelik nie. Vertalings van die Rig Veda ondersteun beide standpunte dat Vediese priesters nie van Ahura Mazda geweet het nie, en dat hulle wel geweet het (vgl bv Rig Veda 5.63.3d en 7b, c asook 5.83.6d).

Ahura Mazda word deur Zoroaster tot 'n posisie verhef wat belangriker en hoër is as wat enige godheid nog in die Antieke Nabye Ooste geniet het (Boyce 1984:32 en Cohn 2001:81). 


\section{ZOROASTRAANSE LEERSTELLINGS}

\subsection{Skepping}

Die Indo-Iranese het van altyd af geglo dat daar in die begin slegs een van alles was - slegs een plant, een dier en een mens. Moontlik het Zoroaster oor hierdie oerenkelvoudigheid gepeins sodat hy by die oortuiging uitgekom het dat daar aan die begin ook slegs een god was. Baie lank terug was Ahura Mazda, die geheelwyse, regverdige en goeie, die enigste god. As eerste oorsaak van alles was hy ongeskape in 'n heelal wat basies goed was. Hy is asha, en skep alles wat in ooreenstemming met asha is (Yasna 44.3-5).

Ahura Mazda het 'n unieke identiteit as skepper en bewaarder van die geordende wêreld (vgl die Gathas op Yasna 44.3-5, 7). Hieruit volg dat hy bo alles en almal aanbid moet word. In die Zoroastraanse belydenis word die godsdiens "die aanbidding van Mazda" genoem (Boyce 1991:141).

Saam met Ahura Mazda as enigste goddelike wese bestaan 'n beginsel wat die teenoorgestelde van asha is - die beginsel van valsheid en verdraaiing, die mag van wanorde wat voortdurend aan't werk in die wêreld is. Die konsep word druj genoem, wat "die Leuen" beteken (vgl bv Yasna 30.3 en 45.2). Die konsep is vir die Iranese selfs meer gelade as die begip druh vir die Vediese Indiërs. Ahura Mazda staan teenoor 'n magtige antagonis met die naam Angra Mainyu, wat die gees is wat die beginsel van vernietiging en aktiewe boosheid beliggaam (Yasna 45.2).

Ahura Mazda en Angra Mainyu is die twee primale geeste wat 'n keuse tussen goed en kwaad moet maak. Ahura Mazda kies asha op grond van sy morele aard, terwyl Angra Mainyu druj ondersteun, op grond van sy morele vervallenheid. Die stryd tussen hierdie twee geeste kenmerk die verlede, hede en toekoms van die bestaande wêreld.

Tot by Zoroaster is die goddelik gevestigde orde dikwels deur wanorde en chaos bedreig, maar dit was tog steeds konstant en stabiel. Die Vediese Indiërs het dit steeds geglo. Die wêreld is in die Rig Veda soos dit nog altyd was en sal wees. Vir Zoroaster is niks egter staties en gewaarborg nie. Angra Mainyu se aanval op asha duur voort en Ahura Mazda beskerm dit steeds, maar daar sal 'n einde aan kom. Die wêreld is 'n oorlogsveld en die oorlog duur voort en sleep die mens daarin mee, maar die einde van die stryd lê voor (O'Flaherty 1976:24 en Cohn 2001:82).

Tyd self is in beweging, op pad vorentoe. Zoroastraanse geskrifte maak 'n belangrike onderskeid tussen "onbeperkte tyd" of ewigheid aan die een kant en 
"beperkte of begrensde tyd" aan die ander kant (Basham 1976:53). Die stryd tussen goed en kwaad geskied binne die grense van "beperkte tyd". Die einde van die stryd sal gepaard gaan met die afhandeling van "beperkte tyd". Wanneer "onbeperkte tyd" aanbreek, kom 'n era van geluksaligheid. Want Angra Mainyu en druj sal vernietig word en asha sal die heerskappy voer tot in ewigheid. Die heelal sal ontslae wees van alle bose magte wat choas teweeg bring. Ahura Mazda se plan sal voltooi wees en die goddelike plan sal vervulling bereik (Cohn 2001:83).

\subsection{Hofhouding}

Die twee oergeeste veg van die begin teen mekaar, en skep hofhoudings om hulle in die stryd by te staan. Hulle antagonisme kom na vore in skepping en téén-skepping as reaksie daarop (Boyce 1979:132).

Ahura Mazda skep deur Spenta Mainyu, wat "heilige gees" beteken, en ooreenstem met Tvastr in die Rig Veda. Heer Wysheid skep eers ses magtige goddelike wesens wat langs hom staan. Een is asha. Die res is Goeie Denke, Heerskappy (reg beheer), Toewyding, Heelheid en Onsterflikheid (Boyce 1992:13). Die groep is die Amesha Spentas ("heilige onsterflikes") en tree volgens die wil van Ahura Mazda op. Zoroastriane aanbid ook die gode van die tradisionele pantheon. Navorsers verskil of Zoroaster hierdie gode reeds as wesens beskou het wat deur Ahura Mazda geskep is, en of die pantheon eers op 'n later stadium deur Zoroastraanse priesters wéér in Zoroastranisme ingelyf is, moontlik om voorsiening te maak vir tradisionaliste (Cohn 2001:83). Die implikasie is dat alles deur Heer Wysheid geskep is.

Met behulp van die ses goddelike wesens bring Ahura Mazda dan die hele geordende wêreld tot stand. Die kosmogonie word later verder uitgewerk, en kan in die Pahlavi Bundahisn gevind word, waarvan dele waarskynlik argaïes is (Anklesaria 1964 bied 'n Engelse vertaling). Die oorspronklike mite dateer waarskynlik selfs nog voor die tyd van Zoroaster, die produk van eeue se nadenke in priesterlike skole. Die Bundahisn vertel hoe die gode die skepping in sewe stadia of "skeppings" gerangskik het. Die eerste en tweede rangskikkings was van die lug, 'n groot ronde skulp van steen, en water, wat helfte van die skulp vul. Hierna word die aarde geskep as 'n groot plat bord wat op die water dryf. Dan word daar in die middel van die aarde 'n enkele plant, 'n enkele dier ('n bul) en 'n enkele mens gestel. Heel laaste word vuur gemaak, in twee vorme: as 
'n sigbare vuur en as 'n onsigbare lewensmag wat alle lewende "skeppings" deurspons (Boyce 1984:14-57).

Aan die begin het die son stil gestaan bó die aarde, en die heelal was bewegingloos, onveranderlik en vasgevang in die middaguur. Die aarde begin beweeg en verander as die lot van die mens, dier en plant verander. In die begin het aldrie in die sentrum van die aarde geleef. Die bul was groot, wit en skerp soos die son en het aan die een kant van die rivier gewoon. Aan die ander kant was die mens, wie se naam Gayo-maretan of in die Pahlavi Gayomard (albei beteken "sterflike lewe") was. Die mens was so breed as lank en het so skerp as die maan geskyn. Verandering begin as die bul en mens deur die gode geoffer word. Uit hulle saad kom die mensdom en diereryk voort (O'Flaherty 1976:139140; Eliade 1979:223-227). So kom die veranderende wêreld tot stand as elke geslag in die dood eindig. Die geordende wêreld bestaan uit die son wat elke dag sy reis van nuuts begin, en die seisoene wat mekaar opvolg. Die wêreld se voortbestaan is gewaarborg en sal nooit tot 'n einde kom nie (Cohn 2001:84).

Zoroaster neem hierdie antieke leerstelling oor wat eerder vrae oor die oorsprong en fisiese aard van die natuur vra, en dink verder oor die morele en geestelike sy van die skepping. Hy herinterpreteer dit radikaal om by sy etiese wêreldbeskouing in te pas. Die profeet plaas elkeen van die sewe "skeppinge" onder die sorg van die sewe Heilige Onsterflikes: die lug onder Heerskappy, water onder Heelheid, die aarde onder Toewyding se sorg, plante onder Onsterflikheid, diere onder Goeie Denke en die mens onder die sorg van Ahura Mazda self, of sy Heilige Gees, terwyl vuur onder asha kom (Boyce 1981:243).

Vuur is reeds deur die Indo-Iranese as goddelik beskou, en Zoroaster stel die reël dat sy volgelinge altyd in die teenwoordigheid van vuur moet aanbid (Darmesteter 1883:97). Terwyl die aanbidder na die vuur kyk, moet hy sy gedagte op geregtigheid en regverdigheid (asha) rig. In Achaemeneïese tye as Zoroastriane hulle eerste tempels bou, word die ruimte wat in ander godsdienste aan 'n beeld gewy word, gebruik om heilige, altyd-brandende vuur te vereer. Tot vandag bid Zoroastriane steeds altyd in die teenwoordigheid van vuur (O'Flaherty 1976:27; Eliade 1979:226).

Die Heilige Onsterflikes sorg nie slegs vir dele van die skepping nie, maar word daarmee geïdentifiseer. Elke Onsterflike woon in die spesifieke deel van die skepping, en sorg so daarvoor. Die Heilige Gees kom woon in elke regverdige mens terwyl die beginsel van orde en waarheid in elke vuur teenwoordig is. Die 
Heilige Onsterflikes is personifikasies van geestelike waardes asook beskermers van die fisiese skepping. Hulle leef aan die sy van Ahura Mazda maar deurdring ook die gehele skepping. So weef Zoroaster die fisiese en geestelike ineen in sy wêreldbeskouing. Die verandering van die nie-liggaamlike in 'n lewende liggaam is hoegenaamd nie ' $n$ degenerasie nie, maar eerder ' $n$ vervolmaking of vervulling. Die materiële is essensieel goed (O'Flaherty 1976:139-140; Cohn 2001:85).

Ahura Mazda skep die geordende wêreld met 'n morele doelwit in die oog, om Angra Mainyu te verslaan. Die heelal vorm die agtergrond waarteen die vyande hulle geveg kan uitbaklei sodat orde teen choas kan oorwin en in niks verander kan word. Die bestaan van die heelal vorm 'n slaggat waarin Angra Mainyu sal trap en waarin hy al sy energie stort om uiteindelik vernietig te word (Zaehner 1961:19; Boyce 1975:192-231).

Die "beperkte tyd" waarin die heelal deur Angra Mainyu aangeval word, staan bekend as "die tyd van mengsel", omdat Angra Mainyu se doelstelling is om die sewe "skeppinge" se suiwerheid te vernietig. Hy deurpriem die lug se harde steen, hy kontamineer die water sodat dit soutagtig word en verander die vrugbare grond in woestyn. Selfs vuur word gekontamineer sodat rook daaruit voortkom, en hy vernietig die eerste lewende wesens, die plant en dier (bul) en mens (Anklesaria 1964:24). Angra Mainyu wat die eerste mens en dier doodgemaak het, is Zoroaster se reïnterpretasie van die oorspronklike kosmogonie. $\mathrm{Hy}$ is verantwoordelik dat verandering en verval in die wêreld ingekom het. Ahura Mazda antwoord hierop deur ' $n$ veelvoud van plante en diere en mense te skep. Angra Mainyu se grootste oorwinning word in sy grootste neerlaag verander as hy met 'n aarde gevul met lewende wesens gekonfronteer word ná sy eerste vernietigingswerk (Anklesaria 1964:31).

\subsection{Offers}

Iranese gode ("die onsterflikes" of "die skitterendes") was tradisioneel goedgesind teenoor mense, maar afhanklik van hulle ondersteuning om hulle arms te sterk in die handhawing van orde en reg. Offers vir antieke Iranese het dieselfde betekenis as vir Vediese Indiërs, as gasvryheid aan iemand van wie 'n guns verwag word en uit dankbaarheid vir dienste gelewer (Cohn 2001:86-87). Aanbidding het egter ' $n$ verdere, belangriker doel, om die gode in staat te stel, te ondersteun en te bemoedig sodat hulle ter wille van die mens die reg kan laat geskied (Darmesteter 1883:126). Gode wat behoorlik aanbid is met woordryke lofprysing en vrygewige offers is beter toegerus en geneig om asha te handhaaf. 
Tussen die lewende wesens wat Ahura Mazda geskep het dra die mens die unieke verantwoordelikheid, wat swaar op hom/haar rus, om die gode in hulle taak te ondersteun.

Die oergeeste moes tussen goed en kwaad, orde en chaos kies. Net so kies elke individu tussen die konstruktiewe en destruktiewe wat deur die twee geeste verteenwoordig word. In die sentrum van Zoroastranisme staan vrye morele keuse by die mens (Boyce 1992:13). Die mens wat vir die goeie kies, word Ahura Mazda se belangrikste protagonis in die geveg teen druj. Hierdie mens werk saam met goddelike magte om die wêreld vir sy heil voor te berei, wanneer alles van chaos verlos sal word. Die Zoroastriaan ondersteun Ahura Mazda deur streng die reinheidswette te onderhou. Die regverdige mens mag byvoorbeeld nie in kontak met 'n lyk kom nie, want die lyk verteenwoordig Angra Mainyu se oorwinning oor asha. Die onrein mens veroorsaak droogte in die somer en diep sneeu in die winter. Alles wat uit die liggaam gewerp word val onder dieselfde kategorie, en so ook diersoorte wat die mens skade aandoen, en instrumente van Angra Mainyu is. Die Zoroastriaan se plig is om reptiele, miere, wolwe en ander gevaarlike diere te vernietig (Boyce 1975:294-307).

Die dualistiese leer stel Zoroastranisme in 'n verhouding tot die kosmos wat verskil van ander antieke kulture, buiten vir die Jode. In ander samelewings is die mens betrokke deur die gode se hand te sterk, terwyl die Zoroastriaan meer direk betrokke is en deur sy keuses en gedrag 'n invloed op die gang van die wêreld uitoefen. Alle mense word hierby betrek, nie slegs 'n klein groepie soos in ander godsdienste nie. Daarmee saam sonder die reinheidsreëls en ritusse die Zoroastriaan af van ander volke, nes die geval met die Jode met heiligheid as een van die sentrale temas van hulle godsdiens.

\subsection{Chiliastiese denke}

Zoroaster se wêreldbeeld is gevorm deur sy ervaring as 'n weerlose, uitgelewerde mens as arm man (Cohn 2001:94). In sy dag bestaan twee soorte stamme: stamme wat van hulle vee leef en slegs na goeie weiding soek, teenoor stamme wat op oorlog uit was en sonder rede mense uitgemoor het. Vroeg in die tweede millennium gaan groepe jong Indo-Ariane met die passe van die Kaukasus na die suide om in die ryk koninkryke as huursoldate te dien. Hulle bring die kuns van oorlog met gevegswaens saam as hulle huis toe keer. Dié 
vorm van oorlogvoering verander gevegskuns in die oosterse Middelandse ryke. Professionele soldate word nou opgelei (Boyce 1991:219).

Zoroaster laat geen genade toe om die mense van die leuen, die agente van druj uit te roei nie (Yasna 46.4). Uit sy ervarings ontstaan sy profesieë, wat milleniaristies of chiliasties van aard is (Chiliastiese profete word konsekwent gebore uit en vind hulle inspirasie in die vernietiging van die antieke lewenswyse wat hulle beleef, en die oorgang na 'n nuwe situasie. Hieruit word die belofte van ' $n$ totale transformasie van bestaan en die vervolmaking van die wêreld gebore (Cohn 1957:124). Zoroaster se profesieë is gebore uit die lyding wat altyd met 'n oorgangsituasie gepaard gaan (Nel 2002:465-466 bespreek hierdie hipotese soos toegepas op die postmoderne situasie).

\subsection{Ná-lewe}

Zoroaster se leer oor die toestand waarin individue hulle na hulle dood bevind asook die staat waarin die aarde gaan bestaan aan die einde van "beperkte tyd" was rewolusionêr vir sy tyd. Vir 'n volledige weergawe moet die Bundahishn geraadpleeg word, wat vertalings insluit van Avestaanse materiaal uit die middel van die eerste millennium, of selfs vroeër. Hoofstuk 34 van die Bundahishn is veral belangrik. Vergelyk ook Boyce se seleksie (1975:109-117, 236-241).

Voor Zoroaster het die Iranese soos die Vediese Indiërs geglo dat die gestorwenes 'n vaal bestaan in die skadu's van die area onder die aarde lei (Boyce 1979:198). Later het die geloof gegroei dat sekere uitverkorenes, soos prinse, soldate en priesters wat aan die vereistes van asha voldoen het en vrygewig in hulle offers aan die gode was, ná hulle dood in 'n paradys in die lug gaan woon waar hulle lig en die son en elke denkbare genieting ervaar. Die lot van elke individu is by 'n brug besluit oor die afgrond tussen lewe en dood. Slegs die gelukkiges kan oor die brug gaan. Die res stort in die afgrond in om vreugdeen geriefloos in die onderwêreld te bestaan (Boyce 1979:213).

Die brug kry 'n nuwe morele inhoud by Zoroaster as oor die mens se gedrag geoordeel word, en hy demokratiseer die paradys (Cohn 2001:96). Enige mens bo die ouderdom van vyftien kan toegang kry, op grond van sy/haar etiese onderskeidinge. As die gewig van goedheid swaarder weeg in die gedagtes, woorde en dade van die mens, kry hy/sy toegang tot die paleise in die lug om in die teenwoordigheid van Ahura Mazda en die Heilige Onsterflikes te leef. As boosheid egter swaarder weeg, gaan die mens na die gebied van Angra Mainyu, 
die tuiste van die Leuen wat 'n plek van pyniging is waar siele gemartel word en slegs stink kos kry en nooit lig sien nie. Die onderwêreld verander in 'n hel, 'n innovasie van Zoroaster (Arbman 1927:339-352; 1928:187-240.

Voorheen is geglo dat die bevoorregtes wat die paradys beërwe ná ' $n$ jaar met hulle liggame verenig word. Zoroaster leer egter dat die siele liggaamloos bestaan tot aan die einde van die "beperkte tyd", wanneer hulle liggame uit die dood opgewek word. Aan die einde van tyd is daar 'n universele liggaamlike opstanding. Hierdie opstanding is net soseer 'n oorspronklike skepping en wonderwerk as by die eerste skepping van alles (Bundahishn 34:4-5).

\subsection{Einde van tyd}

Aan die einde van "beperkte tyd" of "die tyd van mengsel" sal die wêreld van alle boosheid gereinig word, insluitende die bose mense wat daarop gelewe het (Cohn 2001:97). Alle mense wat ooit die lewenslig gesien het, sal in 'n groot byeenkoms saam kom. Elke individu sal daar met sy goeie en bose dade gekonfronteer word. Die mense wat gered word omdat goedheid swaarder weeg, sal soos wit skape geskei word van die bose mense, die swart skape. Dan sal Vuur en die Gees van Genesing die metaal in alle berge en heuwels saam smelt. Die aarde sal 'n groot stroom gesmelte lawa word, en alle mense sal deur die lawa moet gaan. Vir die regverdige sal dit dieselfde wees as om deur warm melk te loop, terwyl die bose mens deur smarte sal gaan en werklik verbrand sal word (Yasna 51.9). Hierdie gedagte ontleen Zoroaster aan 'n antieke stamgebruik waarin 'n mens wat aangekla word oor 'n spesifieke misdaad, veroordeel kan word dat lopende koper oor sy bors gegooi word. As hy onskuldig is, sal die goddelike magte ingryp om hom te red. As hy skuldig is, sal hy sterf. Vergelyk ook die gebruik in Numeri 5:11-31 wanneer 'n man oor sy vrou agterdogtig raak.

Twee millennia later word die vuurvloed deur Zoroastriane geherinterpreteer as ' $n$ reiniging of vaevuur waarin die sondes van die bose mense weggebrand word en hulle saam met die regverdiges die paradys kan ingaan (Boyce 1981:157). Bose mense verruil aan die einde van tyd hulle sinlose, bleek bestaan in die onderwêreld vir smartlike, angswekkende uitwissing. Die regverdiges verruil hulle vreugdevolle bestaan in die hemel vir 'n selfs nog beter bestaan op aarde. Op aarde sal hulle ook die genietinge van hulle liggaam hê terwyl hulle in die hemel slegs die genietinge van die gees kon ervaar. 
Terselfdertyd sal die Heilige Onsterflikes 'n finale oorwinning oor die magte wat deur Angra Mainyu geskep is behaal (Cohn 20012:97-98).

Aan die einde van die geveg sal Ahura Mazda na die wêreld kom om as priester 'n laaste offer te bring. Al die regverdiges sal deel in die vet van hierdie wonderlike bul en die bonatuurlike wit haoma wat geoffer word, en as gevolg van hulle deelname aan die offer sal hulle nie net onsterflik wees nie, maar ook ewig jonk. Ouer mense se liggame sal so oud soos veertig bly, en jongmense sal vir ewig vyftien wees. Angra Mainyu se oorwinning oor die mens deur ouderdom en die dood word finaal ongedaan gemaak (Yasna 47-48).

Angra Mainyu sal dan wegvlug na die skaduagtige duisternis waardeur hy in die wêreld ingekom het. Die lopende metaal sal in die hel invloei en die stank en afval skoon brand. Ook die gaping waardeur die Bose Gees gevlug het sal deur die metaal verseël word (Bundahishn, 34:27). Die aarde sal verander wees. Dit sal plat wees as gevolg van die vloed van lawa. Iran se sneeu-bedekte berge as die produk van Angra Mainyu se aanslag teen orde sal nie meer bestaan nie. Die wêreld sal perfek wees, en mense sal in perfekte harmonie saam leef. Egpare en gesinne sal verenig word en saam leef, maar geen kinders sal meer verwek word nie. Alle mense sal toegewyde Zoroastriane wees, Ahura Mazda en die Heilige Onsterflikes vereer en slegs die goeie doen en dink en sê (Yasna 4950).

Hierdie transformasie word "om wonderlik te maak" (Frashokereti in Avestaans en Frashegird in Pahlavi) genoem. Die Pahlavi-boeke praat ook van die "skeiding", in teenstelling met "die tyd van mengsel" (Basham 1967:241 en Boyce 1992:23). Elke jaar prefigureer die komende toestand van saligheid in die Nuwejaarsfees wat $N \bar{o} R \bar{z} z$ genoem word en tydens die nagewening van die lente plaasvind. Die hergeboorte van die natuur en mense word gevier, terwyl gedink word aan hoe alles nuut gemaak gaan word (Cohn 2001:99).

Wanneer die wêreld "wonderlik" gemaak word, sal alles verander. Alle onvolmaaktheid sal geëlimineer wees. Almal sal in vrede met mekaar leef. Die geskiedenis bestaan nie meer nie en niks kan plaasvind nie. Die wêreld sal onveranderlik wees met 'n god wat gesaghebbend daaroor regeer sonder dat sy gesag op enige wyse uitgedaag word (Zaehner 1961:143).

\subsection{Immanensie van die einde}

Wanneer verwag Zoroastriane dat die wêreld "wonderlik" gemaak sal word? Die Gathas verwag dat dit binnekort sal wees. Die profeet het geglo dat die tyd min 
is, en dat hy op daardie spesifieke oomblik deur Ahura Mazda gestuur is om mense aan te moedig om hulleself te reinig en gereed te kry vir die laaste oordeel. Slegs 'n kort tydjie bestaan voor die transformasie van die wêreld gaan plaasvind (Cohn 2001:99).

Die vroegste geslagte van Zoroastriane moes so teleurgesteld soos die vroegste Christene gewees het dat hulle eskatologiese verwagtinge nie realiseer nie. En hulle troos hulleself langs dieselfde lyne as die Christene, deur hulle profeet as die redder van die wêreld te beskou waarvan hulle teenoor alle mense moet getuig (die duidelikste voorbeeld van die apologie wat Christene aanbied vir die wederkoms wat nie plaasvind nie, is seker in 2 Pet 3:3-14 te vinde - kyk veral na vers 9). Die volgende stap is om die begrip van 'n toekomstige redder te ontwikkel in wie Zoroaster as't ware gereïnkarneer gaan word en wat sy werk op aarde sal kom voltooi (Boyce 1984:125).

Hieruit groei ook 'n geboortemite, rondom Zoroaster. Toe Zoroaster se geboorte moes aanbreek, het Ahura Mazda die vurige heerlikheid geskep en op sy weg gestuur, deur die wêreld van eindelose nagte, son, maan en sterre, en die vuur van die huis van die profeet se grootouers, en in die liggaam van sy grootmoeder, wat geboorte gee aan sy moeder, wat geboorte gee aan die profeet met 'n liggaam van brandende vuur. Ahura Mazda beveel die Heilige Onsterflikes om die siel van die profeet in 'n wonderlike haoma-stam te plaas en sy toekomstige liggaam in die melk van wonderlike koeie. Zoroaster se pa meng die haoma en melk saam en wy die mengsel aan Ahura Mazda, waarop hy en sy vrou dit drink. Nou kan die profeet verwek word, en hy sal gevul wees met goddelike mag en 'n unieke beliggaming van asha. By sy geboorte juig die goeie skepping terwyl die bose koorsagtig na maniere soek om hom te vernietig. Maar hulle energie word verniet gemors. Die profeet se koms verteenwoordig 'n direkte ingryping van die hoogste god in die wêreldgeskiedenis en verseker die uiteindelike vervulling van die goddelike plan (Dinkard 7, hfst 2 soos vertaal in Boyce 1975:72-74).

Volgens die Gathas het Zoroaster reeds oor die probleem gedink dat die einde nie aanbreek nie, en troos gevind daarin om te dink aan "een groter as goed" wat na hom sou kom (Yasna 43.3). Hieruit word die enorme figuur van die Saoshyant, die "toekomstige weldoener", gekonstrueer (Yashts 13 en 19 in die Avesta). Net voor die koms van die Saoshyant sal druj haas die oorwinning oor asha behaal. Die Bose Gees sal beheer van die wêreld oorneem, of so sal dit lyk. Die Saoshyant sal hom finaal kom vernietig. 
Sy geboorte sal selfs nog met meer wonderwerke gepaard gaan as dié van Zoroaster. Die profeet Zoroaster se saad word veilig in 'n meer in die suidooste van Iran bewaar, waar dit deur die siele van 99999 regverdiges opgepas word. Wanneer "beperkte tyd" tot 'n gemartelde einde begin kom, sal 'n maagd met die naam Vispa-taurari (wat "sy wat alles oorwin" beteken) in die meer bad, verwagtend raak met die profeet se saad en 'n seun baar met die naam Azvat-ereta (wat "hy wat waarheid beliggaam" beteken). Asvat-ereta is die Saoshyant, en hy speel 'n sentrale rol in die finale eskatologiese drama. Hy dra die "oorwinnende wapen" teen die vyand waarmee Zoroaster se vorstelike weldoener, Vishtaspa, eens die geveg vir die geloof teen Zoroaster se vyande gewen het (Boyce 1975:218; Cohn 2001:101).

Vir 57 jaar voor "die wonderlik maak" sal die Saoshyant die dooies opwek en aan hulle hulle liggame teruggee. Volgens sommige weergawes sal hy selfs van Ahura Mazda die reg oorneem om onsterflikheid aan die regverdiges te gun. Deur na die wêreld te kyk maak hy dit onsterflik en onvernietigbaar, en so voltooi hy die oorwinning van orde oor chaos en "maak hy die wêreld wonderlik" (Boyce 1981:194).

Die profesie oor die Saoshyant dateer heel moontlik terug tot in die tyd van Zoroaster, maar dien ' $n$ verdere doel: om geslagte Zoroastriane se hoop te versterk dat die wêreld wel nuut gemaak sal word en die bose oorwin sal word. Veral in tye van vervolging en moeilikheid het die geloof in die Saoshyant gefloreer, soos ná Alexander die Grote se oorwinning oor die Iranese en ook ná die Arabiese oorname (Boyce 1981:195). Vandag nog floreer die geloof in die koms van die Saoshyant meer onder die verdrukte Zoroastriane in Iran as onder die Parsis van Indië wat godsdiensvryheid geniet (Boyce 1975:293; Cohn 2001:101-102). Dieselfde rol word vervul deur ' $n$ imminente wederkomsverwagting onder vervolgde en verdrukte Christene, teenoor gevestigde Christene wat die mag asook 'n afgekoelde eskatologiese verwagting in die hand het.

In die sesde eeu vC word Zoroastranisme die staatsgodsdiens van die eerste Iranese ryk. Moontlik het Kores die Grote (549-529) reeds die godsdiens aangehang. Verseker het sy opvolgers dit gedoen, soos inskripsies op die grafte van Darius die Grote (522-486), Xerxes (486-465) en Artaxerxes (465-424) bewys. Elke Achaemeneïese monarg glo dat hyself Heer Wysheid se verteenwoordiger op aarde is (Boyce 1991:187).

Nie alles in die godsdiens wat op die Gathas gebaseer is, is geskik vir 'n staatsgodsdiens nie. Ryksgodsdiens benodig tempels en heilige plekke wat deur 
talle priesters bedien word. Die sisteem is nie ongeduldig dat die uiteindelike transformasie van die wêreld onmiddellik aanbreek nie. Mense met mag het geen behoefte aan indringende en radikale verandering nie. As dominante godsdiens van 'n oorwinnende, stewig gevestigde ryk word dit nodig dat Zoroastranisme se eskatologie verander en afgewater word. Die "wonderlik maak" van die wêreld word offisieel onbepaald uitgestel tot ' $n$ verre toekoms (Cohn 2001:102).

Die nodige hersiening van eskatologie word teen die eerste helfte van die vierde eeu $\mathrm{nC}$ deur priesters gedoen wat ortodokse Zoroastranisme verlaat en Zurvanisme aanhang (Boyce 1981:234-235). Nou word daar gepraat van opeenvolgende wêreldryke, beïnvloed deur spekulasies van Babiloniese astronome oor die "groot jaar". "Beperkte tyd" word in gelyke periodes verdeel. In een van die weergawes bestaan "beperkte tyd" uit 9000 jaar wat in drie periodes van 3000 jaar elk verdeel word. In 'n ander weergawe is die totale lengte 12000 jaar wat in vier periodes verdeel word. In die oorspronklike weergawe was die totale lengte waarskynlik 6000 jaar. In die ander weergawes vorm 6000 jaar ook die periode van gebeure op aarde (Cohn 2001:103). Die apokaliptiese Daniëlvisioene met sy beeld van wêreldryke en -eras leen waarskynlik uit dié Zoroastriaanse teologie.

Die eerste periode bestaan uit voorbereidings vir die kosmiese stryd. In die volgende periode word die geestelike skepping in 'n materiële omskep, en aan die einde hiervan val die bose gees die skepping aan met siekte en dood. Die goeie gees het egter reeds op die aanval gereageer deur die siel van Zoroaster te skep. Die finale periode bestaan uit die voorlopige en finale stryd tussen orde en choas, wat vooraf bepaal is om te eindig in die "wonderlik maak" van die wêreld. Hierdie laaste periode word ook in drie gedeel, en elke periode eindig met die openbaring van 'n Saoshyant. Dit is die Bundahishn se weergawe, met drie Saoshyants.

In hierdie skema lê die huidige oomblik in die periode vóór die openbaring van die eerste Saoshyant. Die implikasie is dat die "wonderlik maak" van die aarde na die verre toekoms verskuif word. Tussen die periode wat Zoroastranisme ryksgodsdiens word en die finale transformasie van die wêreld lê 'n gerieflike 2000 jaar. So verander die priesters Zoroaster se oorspronklike leerstellings om die politieke doelstellings en ideologieë van hulle Achaemeneïese monarge te pas. Zoroastranisme as ryksgodsdiens van die Iranese dinastieë funksioneer tot 'n groot mate op dieselfde basis as die godsdienste van die koninklike huise van ander Nabye Oosterse lande (Koch 1984:34 demonstreer dit goed.). So beskou Darius die Grote homself as 
aangestelde van Ahura Mazda om oor 'n ryk te regeer wat die manifestasie van asha is (vgl Boyce 1979:55 en 1984:115 vir aanhalings van inskripsies). Ander Nabye Oosterse konings het dieselfde verklarings gemaak.

\section{SINTESE}

Die proto-Indo-Iranese stamme het in die tweede helfte van die derde millennium op die steppe van suidelike Rusland gebly. Vir hulle was die wêreld 'n goddelik daargestelde orde wat tydloos en onveranderlik was. Dit het nie beteken dat daar nie moeilikheid was nie. Orde en chaos, goed en kwaad het elke dag teen mekaar te staan gekom, maar in hulle denke kon chaos en die boosheid nooit die finale oorwinning oor orde en goed behaal nie. Die voortbestaan van orde en goedheid was gewaarborg, al is die stryd teen kwaad ook hoe fel.

lewers teen die draai van die tweede millennium trek die Indo-Ariane deur Sentraal-Asië en Afghanistan na die Indusvallei, en die groep wat later bekend staan as die Iranese val Iran binne. Die Vediese Indiërs wat dele van Indië beset en die inheemse inwoners verdryf, kyk steeds na die wêreld asof dit in 'n tydlose ekwilibrium vasgevang is.

Die Iranese breek egter met dié wêreldbeskouing. Die Iranese profeet, Zoroaster, beskou alle bestaan as die geleidelike realisering aan die hand van 'n goddelike plan wat uitloop op die uiteindelike vervulling van die plan en 'n einde aan alles soos dit tans bestaan, sodat slegs die volmaakte voortbestaan tot in ewigheid. Hierin lê die ontstaan van apokaliptiese denke. Zoroaster is die eerste figuur wat ' $n$ bepalende rol in die godsdienstige wêreld speel wat apokaliptisisme in sy godsdiens indra. Hierdie denksisteem sou 'n groot invloed uitoefen op Juda wat in die sesde eeu vC in ballingskap na Babilonië weggevoer word. Die Perse ontset die Jode teen $538 \mathrm{vC}$ en laat hulle toe om na hulle eie land terug te gaan. Die Jode vind in die apokaliptiese denksisteem 'n goeie antwoord op hulle teodisee.

\section{Literatuurverwysings}

Anklesaria, B T 1964. Zand-Ăkāsīh, Iranian or greater Bundahishn. Bombay: Motilal Banarsidass.

Arbman, E 1927. Tod und Unsterblichkeit im vedischen Glauben. Archiv für Religionswissenschaft 25, 339-389. Leipzig.

Arbman, E 1928. Tod und Unsterblichkeit im vedischen Glauben. Archiv für Religionswissenschaft 26, 187-240. Leipzig.

Basham, A L 1967. The wonder that was India. New York: Oxford University Press. 
Boyce, M 1975. A history of Zoroastrianism, Vol 1. Leiden: Brill. (Handbuch der Orientalistik.)

Boyce, M 1979. Zoroastrians: Their religious beliefs and practices. Boston: Routledge.

Boyce, M 1981. A history of Zoroastrianism, Vol 2. Leiden: Brill. (Handbuch der Orientalistik.)

Boyce, M 1984. Textual sources for the study of Zoroastrianism. Manchester: Manchester University Press.

Boyce, M 1991. A history of Zoroastrianism, Vol 3. Leiden: Brill. (Handbuch der Orientalistik.)

Boyce, M 1992. Zoroastrians: Its antiquity and constant vigour. New York: Mazda. (Bibliotheca Persica.)

Cohn, N 1957. The pursuit of the millennium. London: Harper.

Cohn, N 2001. Cosmos, chaos \& the world to come: The ancient roots of apocalyptic faith. 2nd edition. New Haven: Nota Bene.

Darmesteter, J 1883. The Zend-Avesta, part 2. Oxford: Philo.

Eduljee, H E 1980. The date of Zoroaster. Journal of the K R Cama Oriental Institute 48, 103-160.

Eliade, M 1979. A history of religious ideas, Vol 1: From the stone age to the Eleusinian Mysteries, tr by W R Trask. London: Collins.

Kingsley, P 1990. The Greek origin of the sixth-century dating of Zoroaster. Bulletin of the School of Oriental and African Studies 53, 245-264.

Koch, K 1984. Reichsidee und Reichsorganisation im Perserreich. Göttingen: Vandenhoeck und Ruprecht.

Nel, M 2002. Die Hellenisties-Romeinse wêreld en die ontstaan van apokaliptiek en gnostisisme. Verbum et Ecclesia 23(2), 452-467.

Nyberg, H S 1983. Die Religionen des Alten Irans, tr from Swedish. Leipzig: Yale Nota Bene.

O'Flaherty, W D 1976. The origins of evil in Hindu mythology. Berkeley: University of California Press.

Wolpert, S 1982. A new history of India. New York: Oxford University Press.

Zaehner, R C 1961. The dawn and twilight of Zoroastrianism. London: Weidenfeld and Nicolson. 